\title{
Kelola
}

\section{Strategi Perencanaan Pembiayaan Sekolah dalam Peningkatan Mutu di SMP Negeri}

\author{
Ririn Tius Eka Margareta \\ Magister Manajemen Pendidikan \\ Universitas Kristen Satya Wacana \\ 942016021@student.uksw.edu \\ Bambang Ismanto \\ Magister Manajemen Pendidikan \\ Universitas Kristen Satya Wacana \\ bambang.ismanto@staff.uksw.edu
}

\begin{abstract}
The purpose of this study is to determine the school financing planning strategy in improving the quality of schools. Strategy determination using EFE (Internal Factor Evaluation), IFE (Internal Factor Evaluation), and SWOT (Strengths, Weaknesses, Opportunities, and Threats) analysis. This research is a qualitative research focusing on determining financing planning strategy in SMP Negeri 1 Salatiga. Sources of data come from principals and school treasurers. The technique of collecting data using interviews and documentation. Data analysis included: data collection, data reduction, data display and drawing conclusion/verification. The result of the research is the appropriate school financing strategy for SMP Negeri 1 is to implement WO strategy or to support defensive strategy that is strategy that minimmize weakness to exploit opportunity. In other words, schools use the number of human resources and limited costs to the maximum by using the funds owned and utilize the role of committees, parents, and alumni. For example, a school can scale priorities together with committee-related competitions to be followed, communicate school needs to the committee in order to improve the quality of education, and submit proposals to alumni to contest, establish school facilities and infrastructure, or salary of honorary teachers/staff.
\end{abstract}

Keywords: IFE, EFE, school quality, school financing planning strategy, SWOT

\section{Article Info}




\section{PENDAHULUAN}

Tujuan pendidikan merupakan tujuan seluruh pihak yang terkait dalam dunia pendidikan. Pemerintah (Pemerintah Pusat), Pemerintah Daerah, Satuan Pendidikan, dan masyarakat merupakan pihak-pihak yang memiliki peran penting dalam keberhasilan tujuan pendidikan. Tujuan pendidikan nasional yaitu mengembangkan potensi peserta didik agar menjadi manusia yang beriman dan bertakwa kepada Tuhan Yang Maha Esa, berakhlak mulia, sehat, berilmu, cakap, kreatif, mandiri, dan menjadi warga negara yang demokratis serta bertanggung jawab (UndangUndang Nomor 20 Tahun 2003). Peserta didik merupakan input sekaligus output pendidikan yang membutuhkan pendidikan bermutu. Indikator minimal dari pendidikan bermutu dapat ditinjau dari tercapainya Standar Nasional Pendidikan (SNP). Dalam Peraturan Pemerintah Nomor 19 Tahun 2005 tentang Standar Nasional Pendidikan dinyatakan bahwa Standar Nasional Pendidikan (SNP) adalah kriteria minimal tentang sistem pendidikan di seluruh wilayah hukum Negara Kesatuan Republik Indonesia. Standar Nasional Pendidikan (SNP) terdiri dari standar isi, proses, pendidik dan tenaga kependidikan, kompetensi lulusan, sarana dan prasarana, pembiayaan, pengelolaan, dan penilaian. Dengan adanya standar nasional tersebut, maka arah peningkatan mutu pendidikan Indonesia menjadi lebih jelas (Raharjo, 2012: 301). Hal ini ditegaskan juga oleh Hidayah, Susilowati, dan Sukirman (2014: 15-16), yang menyatakan bahwa pemenuh-an SNP dilakukan guna mewujudkan pelaksanaan pendidikan yang bermutu.

Sekolah merupakan lembaga yang diberi kewenangan untuk menghasilkan generasigenerasi penerus bangsa. Sekolah yang bermutu akan menghasilkan output yang bermutu pula. Mutu merupakan suatu konsep atau pandangan mengenai mutu produk yang sesuai harapan dengan tingkat kepuasan tertentu yang dirasakan oleh pelanggan dan seluruh stakeholder (Sallis, 2010: 29-35). Dalam sudut pandang sekolah, mutu sekolah adalah nilai tinggi rendahnya jasa yang diberikan kepada pelanggan baik pelanggan internal maupun eksternal. Pelanggan internal merupakan pelanggan yang berada di dalam sistem sekolah dan berpengaruh terhadap output sekolah (Wijaya, 2012). Pelanggan internal misalnya guru dan siswa memiliki andil untuk mewujudkan output sekolah yang bermutu. Pelanggan eksternal merupakan pelanggan yang ada di luar sistem sekolah dan menerima/ menikmati output sekolah (Wijaya, 2012). Sebagai contoh, pelanggan eksternal misalnya pengelola sebuah perusahaan yang menerima karyawan dari output sekolah. Mereka yang akan menikmati mutu output yang juga merupakan mutu sekolah.

Definisi lain dari mutu adalah pernyataan yang dinamis terkait dengan produk, pelayanan, orang, proses kerja, lingkungan, dan setiap aspek dalam organisasi yang dapat memenuhi atau melebihi harapan pelanggan (Goetsch and Davis, Ishikawa dalam Rahardjo, 2012: 515). Artinya, sekolah dikatakan bermutu jika memberikan pelayanan jasa yang sesuai/ melebihi ekspektasi pelanggan. Guru mengharap supaya sekolah memberi gaji sesuai dengan kebutuhannya maka sekolah yang bermutu akan memberikan gaji sesuai atau lebih dari kebutuhan guru tersebut. Calon siswa akan memilih sekolah yang memiliki banyak prestasi daripada sekolah yang kurang berprestasi maka sekolah bermutu akan mengusahakan sedemikian rupa supaya setiap siswa dan atau guru mampu berprestasi/ bersaing dengan siswa/ guru-guru dari sekolah lain.

Kriteria minimal (nilai kumulatif) pemenuhan SNP yang harus dipenuhi oleh setiap satuan pendidikan merupakan Standar Pelayanan Minimal (SPM) (Permendikbud Nomor 8 Tahun 2017). Sekolah yang hanya memenuhi SNP perlu meningkatkan pelayanan untuk meningkat-kan standar pelayanan sekaligus meningkat-kan mutu sekolah.

Peningkatan mutu pendidikan selama ini belum sesuai dengan harapan karena disebabkan oleh beberapa faktor diantaranya adalah strategi pembangunan pendidikan yang lebih bersifat "input oriented" dan "macro oriented" yang cenderung diatur oleh birokrasi ditingkat pusat (Suti, 2011). Meskipun telah diberlakukan otonomi daerah, campur tangan Pemerintah masih cukup dominan. Hal ini membatasi sekolah khususnya sekolah negeri untuk mengarah pada "customer oriented" yaitu peningkatan mutu yang berfokus pada 
kebutuhan pelanggan. Untuk memenuhi kebutuhan pelanggan sekaligus meningkatkan mutu, sekolah membutuhkan biaya yang terkadang tidak dapat/ kurang jika hanya menggunakan biaya pendidikan dari pemerintah dan sumbangan sukarela.

Standar pembiayaan adalah standar yang mengatur komponen dan besarnya biaya operasi satuan pendidikan yang berlaku selama satu tahun dan terdiri dari biaya investasi, biaya operasional, dan biaya personal (Peraturan Pemerintah Nomor 19 Tahun 2005). Dalam hal ini, pemerintah telah berupaya sedemikian rupa dalam peningkatan mutu pendidikan misalnya melalui pembiayaan berupa Dana Bantuan Operasional Sekolah (BOS), Bantuan Operasional Sekolah Daerah (BOSDA), Bantuan Operasional Pendidikan (BOP), Dana Alokasi Khusus (DAK), dan sebagainya. Berbagai peraturan dan kebijakan juga telah dibuat sedemikian rupa guna peningkatan mutu pendidikan. Namun pertanyaannya adalah sudahkah mutu pendidikan meningkat. Sampai saat ini, kebijakan pemerintah dalam menentukan dan memberikan dana "sama rata" pada satuan pendidikan belum menjamin peningkatan mutu pendidikan secara maksimal. Hal ini dikarenakan setiap sekolah memiliki kebutuhan yang berbeda-beda. Artinya, setiap sekolah membutuhkan dana yang berbeda pula. Misalnya, bagi sekolah yang memiliki banyak siswa-siswi berprestasi akan membutuhkan lebih banyak dana (misalnya untuk lomba) daripada sekolah yang memiliki sedikit siswasiswi berprestasi. Selain itu, jumlah guru dan pegawai tidak tetap (GTT/PTT/honorer) juga tidak merata di setiap sekolah. Hal ini perlu evaluasi dan tindak lanjut penanggung jawab pendanaan pendidikan yaitu Pemerintah, pemerintah daerah, dan masyarakat, serta pihak-pihak terkait.

Strategi Perencanaan Pembiaya-an Sekolah. Pembiayaan pendidikan merupakan tanggung jawab Pemerintah, pemerintah daerah, dan masyarakat (Undang-Undang Nomor 20 Tahun 2003). Biaya satuan pendidikan terdiri atas biaya investasi (lahan pendidikan dan selain lahan pendidikan), biaya operasi (personalia dan nonpersonalia), bantuan biaya pendidikan, dan beasiswa (Peraturan Pemerintah Nomor 48 Tahun 2008). Sumber biaya utama satuan pendidikan di tingkat Sekolah Menengah Pertama (SMP) Negeri berasal dari Pemerintah dan Pemerintah Daerah. Dalam hal ini, pemerintah memiliki kebijakan dan peraturan terkait dengan pembiayaan satuan pendidikan/ sekolah. Pembiayaan sekolah adalah proses dimana pendapatan dan sumber daya yang tersedia digunakan untuk memformulasikan dan mengoperasionalkan sekolah di berbagai wilayah geografis dan tingkat pendidikan yang berbeda-beda (Levin dalam Subarna: 2014). Tidak hanya tingkat dan wilayah geografis, perhitungan kebutuhan sekolah dari berbagai aspek perlu dipertimbangkan dan diputuskan secara bijaksana. Sekolah dengan jumlah siswa sedikit tetapi memiliki lahan dan bangunan sekolah yang luas membutuhkan biaya perawatan yang memadai. Demikian pula dengan sekolah yang memiliki banyak guru/ pegawai tidak tetap membutuhkan biaya operasional untuk menggaji dan memberi tunjangan yang layak.

Dengan kebijakan dan peraturan yang "sama", beberapa sekolah tidak dapat meningkatkan mutu dengan maksimal. Kebijakan dan peraturan yang "sama" misalnya jumlah dana Bantuan Operasional Sekolah (BOS) yang diterima oleh setiap siswa SMP.

Seharusnya, biaya satuan setiap siswa adalah biaya rata-rata per siswa yang dihitung dari total pengeluaran sekolah dibagi seluruh siswa yang ada di sekolah dalam kurun waktu tertentu. Satuan biaya pendidikan tiap siswa merupakan ukuran yang menggambarkan seberapa besar uang yang dialokasikan sekolah (sumber dari Pemerintah, pemerintah daerah, orang tua, dan masyarakat) secara efektif untuk kepentingan siswa dalam menempuh pendidikan, maka sekolah harus mengetahui besaran untuk keperluan penganggaran yang setidaknya mendekati ketepatan. Total pengeluaran sekolah atau besar anggaran pembiayaan pendidikan mencakup: biaya pengembangan guru dan tenaga kependidikan, honor non PNS Guru Tidak Tetap (GTT) dan Honor Non PNS Pegawai Tidak Tetap (PTT), Biaya Operasi Pendidikan Langsung Non Personalia (Belanja Barang dan Jasa), serta pengadaan peralatan penunjang pendidikan/pembelajaran (Belanja Modal) (Hidayah, Susilowati, dan Sukirman, 2014: 15-17).

Dengan pemberian bantuan seperti dana Bantuan Operasional Sekolah dan sumbangan sukarela diharapkan mampu memenuhi kebutuhan sekolah. Pada kenyataannya, setiap sekolah memiliki jumlah pengeluaran dan siswa yang berbeda-beda. Besarnya bantuan dan sumbangan sukarela yang diterima tidak 
dapat menjamin kebutuhan sekolah terpenuhi. Bagi sekolah swasta, kebutuhan sekolah mungkin dapat diatasi dengan iuran siswa namun tidak demikian dengan sekolah negeri. Sesuai Peraturan Pemerintah Nomor 48 Tahun 2008, sekolah (pemerintah/ negeri) tidak diperkenankan melakukan pungutan terhadap siswa. Meskipun memiliki aturan yang berbeda, sekolah swasta maupun negeri membutuh-kan strategi perencanaan pembiayaan yang tepat untuk mempertahankan bahkan meningkatkan mutu sekolah.

Strategi adalah pendekatan secara keseluruhan yang berkaitan dengan pelaksanaan gagasan, perencanaan, dan eksekusi sebuah aktivitas dalam kurun waktu tertentu (Maretsya, Soegiarto, dan Heriyanto, 2015). Strategi pembiayaan meliputi strategi perencanaan (pelaksanaan gagasan), pelaksanaan, evaluasi, dan tindak lanjut. Strategi perencanaan pembiayaan pendidikan pada SMP, diawali dengan disusunnya Visi dan Misi Sekolah, strategi perencanaan dan penyusunan RAPBS dilaksanakan melalui analisis SWOT sederhana (Subarna, 2014: 81). Strategi perencanaan pembiayaan sekolah merupakan bagian penting dari manajemen yang perlu ditentukan sesuai dengan faktor internal dan eksternal suatu perusahaan/ lembaga termasuk sekolah. Selain itu hasil dari penentuan strategi perencanaan akan berimplikasi pada strategi pelaksanaan.

Kebijakan pemerintah terkait dengan pendidikan gratis membuat sekolah tidak perlu lagi memikirkan tentang menghimpun dana dari orang tua dan masyarakat tetapi di sisi lain menjadi gamang bagaimana mengembangkan program pendidikan sesuai keinginan masyarakat sebagai customer (Subarna, 2014: 81). Sekolah yang memiliki input siswa yang kurang baik secara jumlah, akademis dan non akademis biasanya tidak terlalu terbeban dengan peningkatan mutu. Berbeda dengan sekolah yang memiliki jumlah siswa yang banyak dan hampir semua siswa memiliki kemampuan akademik dan atau non akademik yang cemerlang. Sekolah dapat menentukan strategi perencanaan pembiayaan yang tepat untuk memenuhi kebutuhan sekolah termasuk kebutuhan siswa. Strategi pembiayaan yang dapat diterapkan untuk melaksanakan proses pendidikan yang sesuai dengan kebutuhan belajar peserta didik, harus memfokuskan pada program-program yang menjadi objek biaya, supaya efektivitas dan efisiensi pembiayaan pendidikan dapat tercapai (Kurniady, 2011: 43). Dalam hal ini, kemampuan pengelola pembiayaan sekolah dalam menentukan strategi menjadi faktor penting. Salah satu kunci keberhasilan dalam pembangunan pendidikan, terletak pada kemampuan SDM dalam mengelola dana yang tersedia dengan mengacu pada kebutuhan pokok dan skala prioritas program pembangunan pendidikan dari tahun ke tahun secara bertahap dan berkesinambungan sesuai dengan perencanaan program (Ferdi, 2013: 566). Dalam peningkatan mutu sekolah juga dibutuhkan SDM yang mampu mengelola dana dan menentukan strategi pembiayaan dari strategi perencanaan sampai strategi tindak lanjut pembiayaan.

Berdasarkan studi pendahuluan, hal serupa dialami oleh SMP Negeri 1 Salatiga yaitu dana BOS hanya memenuhi SNP minimal. Banyaknya siswa-siswi berprestasi dan berbakat serta banyak GTT/PTT membutuhkan dana yang cukup besar. Sesuai dengan Peraturan Menteri Pendidikan dan Kebudayaan Nomor 44 Tahun 2012, SMP Negeri 1 Salatiga tidak menerima pungutan melainkan sumbangan sukarela. Meskipun demikian, biaya untuk meningkatkan mutu sekolah masih kurang. Salah satu faktor penyebabnya yaitu strategi perencanaan pembiayaan sekolah yang sekolah miliki belum tepat. Dalam penyusunan perencanaan anggaran, banyak sekolah tidak mengawali dengan analisis kebutuhan (need assesment) lingkungan internal dan eksternal atau analisis SWOT (Haryati, 2011: 73). Oleh karena itu, penulis hendak menentukan strategi perencanaan pembiayaan di SMP Negeri 1 Salatiga guna meningkatkan mutu sekolah. Penentuan strategi perencanaan pembiayaan menggunakan analisis IFE, EFE, dan SWOT sebagai teknik analisis dengan mengetahui faktor internal (kekuatan dan kelemahan) dan faktor eksternal (peluang dan ancaman) sekolah.

Analisis EFE, IFE, dan SWOT. Analisis EFE (External Factor Evaluation) dan IFE (Internal Factor Evaluation) digunakan untuk mengetahui kondisi internal dan 
eksternal suatu perusahaan dan dirumuskan menjadi strategi yang mendetail melalui analisi SWOT (Strengths (S), Weakness (W), Opportunitiess $(O)$ dan Threats $(T)$ ) (Sudarma, 2012). Dalam mengembangkan Matriks EFE/ IFE, faktor-faktor eksternal yang ditemukan diberi bobot dengan skala 0,0 (tidak penting) 1,0 (sangat penting) dan total seluruh bobot harus sama dengan satu, kemudian diberi rating/ nilai antara 1-4, dan skor bobot dihitung dari hasil perkalian bobot dengan nilai. Penentuan bobot dan skor menggunakan skala prioritas. Berdasarkan perhitungan skor faktor internal dan eksternal, selanjutnya dihitung skor faktor internal pada tabel IFE dihitung Selisih Total Kekuatan dan Total Kelemahan (S - W) dan pada tabel EFE dihitung Selisih Total Peluang dan Total Ancaman $(\mathrm{O}-\mathrm{T})$. Besarnya IFE dan EFE yang telah dianalisis dimasukan ke dalam diagram keputusan analisis SWOT yaitu hasil IFE berada pada sumbu x dan hasil EFE berada pada sumbu y.

SWOT merupakan salah satu teknik analisis yang dapat digunakan untuk menentukan strategi-strategi yang dapat membantu perusahaan/ lembaga termasuk sekolah dalam peningkatan mutu. SWOT adalah metode perencanaan strategis yang digunakan untuk mengevaluasi kekuatan (strengths), kelemahan (weaknesses), peluang (opportunities), dan ancaman (threats) dalam suatu proyek atau suatu spekulasi bisnis (Wikipedia, tt). Analisis SWOT adalah identifikasi berbagai faktor secara sistematis dari berbagai faktor sistematis untuk merumuskan strategi perusahaan (Maretsya, Soegiarto, dan Heriyanto, 2015). Faktor yang dimaksud yaitu internal (strengths dan weakness) faktor eksternal (opportunities dan threats). Kekuatan (Strengths) dapat diartikan sebagai segala sesuatu yang dimiliki oleh sekolah dan mendukung visi, misi, dan tujuan sekolah. Kelemahan (Weakness) adalah hal-hal yang menjadi kelemahan sekolah misalnya kinerja pegawai yang buruk. Peluang (Opportunitiess) adalah kesempatan yang berasal dari luar sekolah dan dapat dimanfaatkan untuk mencapai visi, misi, dan tujuan sekolah. Ancaman/ hambatan (Threats) adalah hal-hal yang dapat mengamcam/ menghambat pencapaian sekolah misalnya munsul pesaing baru yang lebih unggul.

Secara lebih terperinci, strategi-strategi yang dapat dihasilkan dari analisis SWOT dijelaskan dalam tabel berikut:

Tabel 1. Strategi-strategi berdasarkan analisis SWOT (Marimin, 2004: 60)

\begin{tabular}{|c|c|c|}
\hline IFA/EFA & STRENGTHS (S) & WEAKNESS (W) \\
\hline OPPORTUNITIES (O) & $\begin{array}{l}\text { Strategi SO } \\
\text { Menciptakan strategi yang } \\
\text { menggunakan kekuatan untuk } \\
\text { memanfaatkan peluang. Digunakan } \\
\text { jika perusahaan/ } \\
\text { pada kuadran I lembaga berada }\end{array}$ & $\begin{array}{l}\text { Strategi WO } \\
\text { Menciptakan strategi yang } \\
\text { meminimalkan kelemahan untuk } \\
\text { memanfaatkan peluang. Digunakan } \\
\text { jika perusahaan/ lembaga berada } \\
\text { pada kuadran III }\end{array}$ \\
\hline TREATHS (T) & $\begin{array}{l}\text { Strategi ST } \\
\text { Menciptakan strategi yang } \\
\text { menggunakan kekuatan untuk } \\
\text { mengatasi ancaman. Digunakan jika } \\
\text { perusahaan/ lembaga berada pada } \\
\text { kuadran II }\end{array}$ & $\begin{array}{l}\text { Strategi WT } \\
\text { Menciptakan strategi yang } \\
\text { meminimalkan kelemahan dan } \\
\text { menghindari ancaman. Digunakan } \\
\text { jika perusahaan/ lembaga berada } \\
\text { pada kuadran IV }\end{array}$ \\
\hline
\end{tabular}

Suatu organisasi harus membuat perencanaan dan pendefinisian strategi yang tepat agar dapat membuat keputusan mengenai pengalokasian sumberdaya yang ada secara tepat dalam menjalankan strategi tersebut dan untuk mengukur dan melihat apakah strategi yang direncanakan dan dijalankan berhasil atau tidak, maka harus dipilih pengukuran yang akurat, seimbang, terintegrasi dan selaras (Susanto, 2014: 11-13). Dalam hal ini, analisis SWOT dapat dijadikan salah satu alat ukur dalam menentukan strategi yang tepat. Melalui kekuatan dan peluang yang ada, sekolah dapat meningkatkan mutu. Selain itu, sekolah dapat meminimalkan kelemahan dan ancaman yang ada dengan strategi yang tepat. 
Penelitian tentang strategi pembiayaan sekolah sulit ditemukan karena belum banyak yang melakukan penelitian terkait. Penelitian Sudarsana (2016) menyatakan bahwa perkembangan ekonomi merupakan salah satu alat untuk memenuhi permintaan masyarakat terhadap pendidik-an, karena pendidikan memerlukan biaya. Hal tersebut menegaskan bahwa upaya sekolah baik dalam bentuk kegiatan atau program membutuhkan biaya untuk memenuhi permintaan pelanggan sekaligus meningkatkan mutu. Hal ini ditegaskan dalam penelitian Suti (2011), unsur pendanaan/pembiayaan pendidikan yang memungkinkan semua program pendidikan di lembaga pendidikan/ sekolah dapat berlangsung. Tanpa biaya, kegiatan tidak terlaksana yang berarti tujuan kegiatan/ program pendidikan/ sekolah tidak tercapai.

\section{METODE PENELITIAN}

Penelitian ini merupakan penelitian kualitatif yang memaparkan tentang strategi perencanaan pendidikan. Dalam penelitian ini, tingkat strategi yang digunakan adalah tingkat unit/ fungsional dengan lokasi penelitian di SMP Negeri 1 Salatiga. Subyek penelitian yaitu kepala sekolah dan bendahara. Pengumpulan data melalui wawancara dan studi dokumen. Data yang terkumpul direduksi dengan cara mengidentifikasi faktor internal dan eksternal sekolah. Kemudian data diolah sesuai dengan aturan analisis IFE, EFE, dan SWOT dan disajikan dalam bentuk tabel dan diagram. Setelah itu strategi yang dihasilkan merupakan kesimpulan penelitian. Dalam penelitian ini juga dilakukan triangulasi sumber dengan melakukan klarifikasi kebenaran data kepada subyek penelitian.

\section{HASIL PENELITIAN DAN \\ PEMBAHASAN}

Hasil Penelitian

Faktor internal sekolah di SMP Negeri 1 Salatiga yaitu: 1) Kekuatan: a) Sekolah memiliki kantin dan koperasi sebagai sumber pendapatan internal lainnya, b) Partisipasi karyawan (bukan pengelola) dalam pengelolaan pembiayaan, dan c) Partisipasi siswa dalam pembiayaan sekolah; dan 2) Kelemahan: a) Jumlah SDM yang mengelola pembiayaan sekolah, b) Pembiayaan untuk lomba, c) Pembiayaan untuk pengadaan/ perbaikan sarana dan prasarana sekolah, dan d) Biaya untuk gaji guru/tenaga honorer.

Faktor eksternal sekolah di SMP Negeri 1 Salatiga yaitu: 1) Peluang: a) Dana rutin dari Pemerintah dan Pemerintah Daerah, b) Peran komite dan orang tua (misalnya memberi dana sukarela), dan c) Kontribusi/ bantuan dari alumni; 2) Ancaman/ hambatan: a) Peran pemerintah dalam pengadaan tenaga PNS, b) Keterlambatan pemerintah dan penerbit buku merealisasikan pengadaan buku Kurikulum 2013 (K-13), dan c) Honor untuk guru/ tenaga honorer.

Pengelola pembiayaan sekolah telah berupaya meningkatkan mutu dengan menentukan skala prioritas. Pertimbangan terkait anggaran yang dimiliki dan prioritas pemenuhan kebutuhan sekolah dilakukan bersama seluruh stakeholders sekolah. Mulai dari penyebaran angket kebutuhan selama satu tahun ajaran hingga pengambilan keputusan, didiskusikan secara kekeluargaan oleh pihakpihak terkait (Kepala sekolah, bendahara, guru, karyawan, dan komite).

\section{Pembahasan}

Berdasarkan faktor internal dan eksternal Sekolah dapat diperoleh analisis sebagai berikut: 
Strategi Perencanaan Pembiayaan Sekolah Dalam ... | Ririn T. E. Margareta \& Bambang Ismanto

Tabel 2. Faktor Internal dan Faktor Eksternal Sekolah di SMP Negeri 1 Salatiga

KEKUATAN

\begin{tabular}{|c|l|l||l|l|}
\hline No & \multicolumn{1}{|c||c|}{ Nama Faktor } & \multicolumn{1}{|c|}{ Bobot } & Nilai & Skor Bobot \\
\hline 1 & $\begin{array}{l}\text { Sekolah memiliki kantin dan koperasi sebagai sumber pendapatan } \\
\text { internal lainnya. }\end{array}$ & 0,2 & 8 & 0,8 \\
\hline 2 & $\begin{array}{l}\text { Partisipasi karyawan (bukan pengelola) dalam pengelolaan } \\
\text { pembiayaan }\end{array}$ & 0,15 & 2 & 0,3 \\
\hline 3 & Partisipasi siswa dalam pembiayaan sekolah & 0,1 & 1 & 0,1 \\
\hline
\end{tabular}

KELEMAHAN

\begin{tabular}{|l|l|l|l|l|}
\hline No & \multicolumn{1}{|c|}{ Nama Faktor } & \multicolumn{1}{|c|}{ Bobot } & \multicolumn{1}{c|}{ Nilai } & Skor Bobot \\
\hline 1 & Jumlah SDM yang mengelola pembiayaan sekolah & 0,3 & 3 & 0,9 \\
\hline 2 & Pembiayaan untuk lomba & 0,15 & 2 & 0,3 \\
\hline 3 & $\begin{array}{l}\text { Pembiayaan untuk pengadaan/ perbaikan sarana dan prasarana } \\
\text { sekolah }\end{array}$ & 0,05 & 2 & 0,1 \\
\hline 4 & Biaya untuk gaji guru/tenaga honorer & 0,1 & 2 & 0,2 \\
\hline
\end{tabular}

Tabel 3. Faktor Eksternal Sekolah di SMP Negeri 1 Salatiga

PELUANG

\begin{tabular}{|l|l|l|l|l|}
\hline No & Nama Faktor & Bobot & Nilai & Skor Bobot \\
\hline 1 & Dana rutin dari Pemerintah dan Pemerintah Daerah & 0,25 & 4 & 1 \\
\hline 2 & Peran komite dan orang tua (misalnya memberi dana sukarela) & 0,2 & 4 & 0,8 \\
\hline 3 & Kontribusi/ bantuan dari alumni & 0,1 & 1 & 0,1 \\
\hline \multirow{2}{*}{} & & 1,9 \\
\cline { 2 - 4 }
\end{tabular}

\section{ANCAMAN}

\begin{tabular}{|l|l|l|l|l|}
\hline No & Nama Faktor & Bobot & Nilai & Skor Bobot \\
\hline 1 & Peran pemerintah dalam pengadaan tenaga PNS & 0,2 & 1 & 0,2 \\
\hline 2 & $\begin{array}{l}\text { Keterlambatan pemerintah dan penerbit buku merealisasikan pengadaan } \\
\text { buku Kurikulum 2013 (K-13) }\end{array}$ & 0,1 & 1 & 0,1 \\
\hline 3 & Honor untuk guru/ tenaga honorer & 0,15 & 1 & 0,15 \\
\cline { 2 - 4 } & & 0,45 \\
\cline { 2 - 4 }
\end{tabular}


Berdasarkan Tabel EFE dan EFE dapat dihitung:

Total skor bobot kekuatan - Total skor bobot kelemahan $=1,2-1,5=-0,3$
Total skor bobot peluang - Total skor bobot ancaman $=1,9-0,45=1,45$

Sehingga diperoleh titik $(-0,3,1,45)$ pada diagram SWOT atau berada di kuadran 2 seperti gambar di bawah ini:

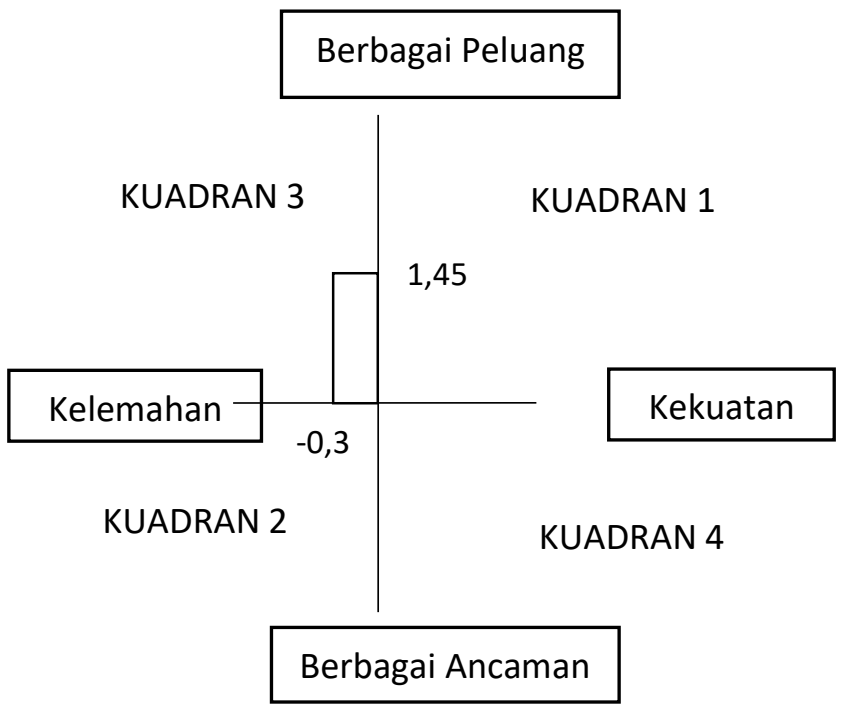

Gambar 1. Diagram SWOT: Perencanaan Strategi Pembiayaan Sekolah

Berdasarkan diagram SWOT di atas dapat diketahui bahwa stategi yang cocok dengan kondisi internal dan eksternal sekolah adalah strategi WO atau mendukung strategi defensive yaitu strategi yang meminimalkan kelemahan untuk memanfaatkan peluang. Berikut strategistrategi alternatif yang disajikan pada Tabel 4:

Tabel 4. Strategi-Strategi Alternatif dalam Perencanaan Strategi Pembiayaan Sekolah

\begin{tabular}{|c|c|c|}
\hline IFA/EFE & $\begin{array}{l}\text { Kekuatan (S): } \\
\text {-Sekolah memiliki kantin dan } \\
\text { koperasi sebagai sumber } \\
\text { pendapatan internal lainnya. (S1) } \\
\text {-Partisipasi karyawan (bukan } \\
\text { pengelola) dalam pengelolaan } \\
\text { pembiayaan (S2) } \\
\text {-Partisipasi siswa dalam } \\
\text { pembiayaan sekolah (S3) }\end{array}$ & $\begin{array}{l}\text { Kelemahan (W): } \\
\text {-Jumlah SDM yang mengelola } \\
\text { pembiayaan sekolah (W1) } \\
\text {-Pembiayaan untuk lomba (W2) } \\
\text {-Pembiayaan untuk pengadaan/ } \\
\text { perbaikan sarana dan prasarana } \\
\text { sekolah (W3) } \\
\text {-Biaya untuk gaji guru/tenaga } \\
\text { honorer (W4) }\end{array}$ \\
\hline Peluang $(\mathrm{O})$ & $\begin{array}{l}\text { Strategi SO: } \\
\text {-Membentuk grup alumni untuk } \\
\text { menggali dana guna menaikkan } \\
\text { mutu (S2, O3). }\end{array}$ & $\begin{array}{l}\text { Strategi WO: } \\
\text {-Membuat skala prioritas bersama } \\
\text { dengan komite terkait lomba- } \\
\text { lomba yang akan diikuti. (W2, O1) }\end{array}$ \\
\hline $\begin{array}{l}\text { Pemerintah Daerah (O1) } \\
\text {-Peran komite dan orang tua } \\
\text { (misalnya memberi dana } \\
\text { sukarela) }(\mathrm{O} 2)\end{array}$ & $\begin{array}{l}\text {-Menambah varian penjualan yang } \\
\text { dibutuhkan oleh warga sekolah } \\
(\mathrm{S} 1, \mathrm{O} 2, \mathrm{O} 3) \text {. }\end{array}$ & $\begin{array}{l}\text {-Mengkomunika- sikan kebutuhan } \\
\text { sekolah kepada komite dalam } \\
\text { rangka meningkatkan mutu } \\
\text { pendidikan (W2, W3, W4, O2) }\end{array}$ \\
\hline $\begin{array}{l}\text {-Kontribusi/ bantuan dari alumni } \\
\text { (O3) }\end{array}$ & & $\begin{array}{l}\text {-Mengajukan proposal kepada } \\
\text { alumni untuk mengikuti lomba, } \\
\text { mengadakan sarana dan prasarana } \\
\text { sekolah, atau gaji guru/ tenaga } \\
\text { honorer. (W4, W2, W3, O3) }\end{array}$ \\
\hline
\end{tabular}




\begin{tabular}{|c|c|c|}
\hline $\begin{array}{c}\text { Ancaman }(\mathrm{T}) \\
\text { Peran pemerintah dalam } \\
\text { pengadaan tenaga PNS (T1) }\end{array}$ & $\begin{array}{l}\text { Strategi ST: } \\
\text {-Mengopti-malkan bantuan } \\
\text { pegawai (bukan pengelola) dalam } \\
\text { mengelola pembiayaan. }\end{array}$ & $\begin{array}{l}\text { Strategi WT: } \\
\text {-Mensosialisasikan cara merawat } \\
\text { saran dan prasarana yang dimiliki } \\
\text { oleh sekolah }(\mathrm{W} 3, \mathrm{~T} 3) \text {. }\end{array}$ \\
\hline $\begin{array}{c}\text { Keterlambatan pemerintah dan } \\
\text { penerbit buku merealisasikan } \\
\text { pengadaan buku Kurikulum } 2013 \\
(\mathrm{~K}-13)(\mathrm{T} 2)\end{array}$ & $\begin{array}{l}\text {-Mengadakan pelatihan terkait } \\
\text { pengelolaan pembiayaan bagi } \\
\text { karyawan yang terlibat/ } \\
\text { diperbantukan dalam mengelola } \\
\text { keuangan }(\mathrm{S} 1, \mathrm{~T} 3)\end{array}$ & \\
\hline $\begin{array}{l}\text { Honor untuk guru/ tenaga honorer } \\
\qquad(\mathrm{T} 3)\end{array}$ & $\begin{array}{ll}\text {-Mengajukan } & \text { permintaan } \\
\text { penambahan tenaga } & \text { PNS dari } \\
\text { Pemerintah }(\mathrm{S} 1, \mathrm{~T} 3) . & \end{array}$ & \\
\hline
\end{tabular}

Strategi-strategi pembiayaan sekolah merupakan upaya untuk mencapai tujuan sekolah yaitu terselenggaranya pendidikan yang sesuai dengan kebutuhan siswa pada khusunya dan masyarakat pada umumnya. Hal ini sejalan dengan pendapat Sudarsana (2016) dan Suti (2011) bahwa pendidikan memerlukan biaya untuk memenuhi permintaan masyarakat dan melaksanakan seluruh program pendidikan. Strategi pembiayaan sekolah mempengaruhi mutu sekolah yang bersangkutan. Sependapat dengan hal tersebut, Asmawi (2010) menyatakan bahwa pembiayaan merupakan salah satu aspek yang menentukan mutu pendidikan. Lebih luas lagi, hasil kajian Ferdi (2013) menyatakan bahwa pembiayaan merupakan proses yang kompleks sehingga strategi perencanaan pembiayaan sekolah merupakan hal yang krusial. Pentingnya perencanaan strategi pembiayaan sekolah dalam meningkatkan mutu perlu diketahui, disadari, dan ditinjau ulang oleh pihak-pihak terkait sehingga membawa perubahan positif bagi keberlangsungan dan pencapaian tujuan sekolah.

Sumber pembiayaan dapat berasal dari pemerintah, sumbangan, dan usaha lain yang sesuai dengan peraturan yang berlaku. Bagi sekolah swasta misalnya pesantren, biaya dapat berasal dari pungutan (Rifqi, 2015). Hal ini berarti, setiap sekolah dan pihak-pihak terkait perlu mengidentifikasi peluang-peluang untuk sumber pembiayaan yang mungkin dapat digali dan digunakan untuk mencapai tujuan sekolah termasuk melaksanakan program dan memenuhi kebutuhan pelanggan pendidikan.

\section{SIMPULAN DAN SARAN Simpulan}

Berdasarkan pembahasan dapat disimpulkan bahwa strategi pembiayaan yang tepat bagi SMP N 1 Salatiga yaitu menerapkan strategi WO atau mendukung strategi defensive yaitu strategi yang meminimalkan kelemahan untuk memanfaatkan peluang. Dengan kata lain sekolah menggunakan jumlah SDM dan biaya terbatas secara maksimal dengan menggunakan dana yang dimiliki serta memanfaatkan peran komite, orang tua, dan alumni. Misalnya sekolah dapat membuat skala prioritas bersama dengan komite terkait lomba-lomba yang akan diikuti, mengkomunikasikan kebutuhan sekolah kepada komite dalam rangka meningkatkan mutu pendidikan, dan mengajukan proposal kepada alumni untuk mengikuti lomba, mengadakan sarana dan prasarana sekolah, atau gaji guru/ tenaga honorer.

\section{Saran}

Saran diberikan kepada:

1) Pemerintah membuka kesempatan kepada CPNS untuk menjadi PNS dan ditempatkan di sekolah-sekolah yang membutuhkan. Dengan diangkatnya CPNS, biaya yang dimiliki sekolah dapat digunakan untuk membiayai hal lainnya guna peningkatan mutu,

2) Kepala sekolah melakukan analisis faktor internal dan eksternal secara berkala sehingga dapat membuat strategi yang lebih baik, dan 
3) Masyarakat diharapkan lebih peduli dengan pembiayaan sekolah karena biaya merupakan salah satu unsur yang penting dalam peningkatan mutu dan pencaaian visi dan misi sekolah.

\section{DAFTAR PUSTAKA}

Asmawi, M. R.2010. Strategi meningkatkan lulusan bermutu di perguruan tinggi. Makara Hubs-Asia, 8 (3).

Ferdi, W. P. 2013. Pembiayaan Pendidikan: Suatu Kajian Teoritis. Jurnal Pendidikan dan Kebudayaan, 19 (4): 565-578.

Haryati, S. 2011. Pengembangan Model Manajemen Pembiayaan Sekolah Menengah Pertama (SMP) Rintisan Sekolah Bertaraf Internasional (RSBI) di Kota Magelang, 36 (2): 64-86.

Hidayah, I., Susilowati, E. dan Sukirman. 2014. Analisis Pembiayaan Pendidikan SMA di Kota Semarang. Riptek, 8 (2): 13-22. Indonesia, P. R. 2003. Undang-Undang Republik Indonesia Nomor 20 Tahun 2003 Tentang Sistem Pendidikan Nasional.

Kebudayaan, M. P. 2012. Peraturan Menteri

Pendidikan dan Kebudayaan Nomor 44

Tahun 2012 tentang Pungutan dan

Sumbangan Biaya Pendidikan pada

Satuan Pendidikan Dasar.

Kementerian Hukum, HAM. 2008. Peraturan

Pemerintah Nomor 48 Tahun 2008 tentang Pendanaan Pendidikan.

Kurniady, D. A. 2011. Pengelolaan Pembiayaan Sekolah Dasar Di Kabupaten Bandung. Jurnal Penelitian Pendidikan 12 (1): 34.

Maretsya, A., \& H Eddy Soegiarto K, H. 2015. Analisis strategi pembiayaan (finance) dalam upaya merebut pangsa. Ekonomia, 4(2): 185-191.

Marimin. 2004. Teknik dan Aplikasi Pengambilan Kriteria Majemuk. Jakarta: Grasindo.

Peraturan Menteri Pendidikan Dan Kebudayaan Republik Indonesia Nomor 8 Tahun 2017 Tentang
Petunjuk Teknis Bantuan Operasional Sekolah

Peraturan Pemerintah Nomor 19 Tahun 2005 tentang Standar Nasional Pendidikan.

Raharjo, S. B. 2012. Evaluasi trend kualitas pendidikan di indonesia. Jurnal Penelitian dan Evaluasi Pendidikan, 16(2): 511-532.

Rifqi, A. 2014. Strategi Peningkatan Dan Pemanfaatan Sumber Pembiayaan Mandiri di Pondok Pesantren, 24 (4): 325.

Sallis, E. 2010. Total Quality Management in Education (Manajemen Mutu Pendidikan). Yogyakarta: IRCiSoD.

Subarna, B. 2014. Pendidikan Gratis Sekolah Menengah Pertama: Antara Harapan dan Kenyataan. Yogyakarta: Deepublish.

Sudarma, M. 2012. Analisis Swot Sebagai Dasar Perumusan Dan Penerapan Strategi Pada Perusahaan (Studi Kasus di Telkom Malang). Jurnal Ilmiah Mahasiswa FEB, 1(2).

Sudarsana, I. K. (2016). Peningkatan Mutu Pendidikan Luar Sekolah Dalam Upaya Pembangunan Sumber Daya Manusia. Jurnal Penjaminan Mutu, 1(1): 1-14.

Susanto, A. B. 2014. Manajemen Strategik Komprehensif untuk Mahasiswa dan Praktisi. Jakarta: Erlangga.

Suti, M. 2011. Strategi Peningkatan Mutu di Era Otonomi Pendidikan. Jurnal Medtek, 3.

Wijaya, D. 2012. Pemasaran Jasa Pendidikan. Jakarta: Salemba.

Wikipedia. (tt). Analisis SWOT. Diakses dari https://id.wikipedia.org/wiki/Analisis_ SWOT pada tanggal 14 Agustus 2017. 